\title{
Home stories: immigrant narratives of place and identity in contemporary Ireland
}

\section{Mary Gilmartin \& Bettina Migge}

To cite this article: Mary Gilmartin \& Bettina Migge (2015) Home stories: immigrant narratives of place and identity in contemporary Ireland, Journal of Cultural Geography, 32:1, 83-101, DOI: 10.1080/08873631.2014.1000576

To link to this article: https://doi.org/10.1080/08873631.2014.1000576

曲 Published online: 03 Feb 2015.

Submit your article to this journal

Џ Article views: 848

Q View related articles $\sqsubset$

View Crossmark data

4 Citing articles: 6 View citing articles 


\title{
Home stories: immigrant narratives of place and identity in contemporary Ireland
}

\author{
Mary Gilmartin $^{\mathrm{a} *}$ and Bettina Migge ${ }^{\mathrm{b}}$ \\ ${ }^{a}$ Department of Geography, Maynooth University-National University of Ireland \\ Maynooth, Maynooth, Co. Kildare, Ireland; ${ }^{b}$ School of Irish, Celtic Studies, Irish \\ Folklore and Linguistics, University College Dublin, Dublin, Ireland
}

\begin{abstract}
This paper discusses immigrant identity and place in contemporary Ireland. It draws from a longitudinal research project that involved recent immigrants to Ireland. Participants in the project came from 18 different countries, and ranged in age from 22 to 68 . Their reasons for moving to Ireland were varied, and included work, adventure, and personal relationships. Combining insights from sociolinguistics and human geography, the paper first considers the different ways in which immigrants to Ireland narrate place and identity, paying particular attention to content and linguistic strategies. It then provides a more detailed discussion of the relationship between immigrant identity and place through a focus on the concept of "home," highlighting the linguistic strategies and means that immigrants used to discursively construct notions of home and identity in their interviews. The paper concludes by arguing that detailed discourse level analysis of people's narratives of place offers new insights into the relationship between immigrant identity and place.
\end{abstract}

Keywords: migration; identity; place; home; language; Ireland

\section{Introduction}

My heart stays with my parents ... but my breath is here.

So said Tomaz, ${ }^{1}$ whom we interviewed as part of a recent research project in Ireland. ${ }^{2}$ We have opened with this quote because it sums up many of the difficulties we encounter when talking about broader questions of identity and place. In particular, it shows the complicated relationship between immigrant identity and place: Tomaz is pulled between two different places: connected to both and, as a consequence, whole in neither. Research on immigrant identity and place also highlights the complicated nature of the relationship and takes a variety of forms. One approach focuses primarily on how identities are changed through the act of migration, for example through changing gender

\footnotetext{
*Mary Gilmartin is Senior Lecturer in the Department of Geography, Maynooth University-National University of Ireland Maynooth, Maynooth, Co. Kildare, Ireland. Email: mary.gilmartin@nuim.ie
} 
roles or different racial positioning (for overviews, see Pessar and Mahler 2003; Silverstein 2005). Another approach focuses on how places are changed by immigrants, such as through the development of new religious landscapes (for overviews, see Peach 2002; Kong 2010). There is also a growing body of work that aims to conceptualize the relationship between place and immigrant identity in a more integrated way. For example, work on transnationalism and translocalism shows the ways in which both places and identities are connected and changed through the experience of migration (Conradson and Mckay 2007; Levitt and Jaworsky 2007; Brickell and Datta 2011). Transnational and translocal approaches have been particularly important in foregrounding concepts such as "belonging" and "home" that allow the relationship between place and immigrant identity to be understood in more nuanced ways (see Ehrkamp 2005; Blunt and Dowling 2006; Mee and Wright 2009; Antonsich 2010; Ralph and Staeheli 2011; van Riemsdijk 2014; Wright 2014). The quote from Tomaz shows this very clearly, as he articulates the different ways in which he as a migrant is connected to different places: his head in Ireland, his heart in his country of origin, and Tomaz unsure of exactly where home is.

In this paper, we consider the relationship between immigrant identity and place in more detail through a specific focus on immigrants living in Ireland. The paper is based on a larger qualitative research project that ran between 2008 and 2011, where we conducted repeat interviews with 60 recent immigrants to Ireland. Here, we focus on the role of narrative, in particular how these recent immigrants narrate their understanding of place. Calls for a focus on the relationship between language and place are not new: Yi-Fu Tuan (1991, p. 694), for example, insisted on the need to take language seriously as part of the process of place-making and Sarbin (1983) argued that an understanding of "place identity" can only be achieved through an analysis of how persons are narratively positioned in time and space, including physical and metaphorical space. As Brickell points out, however, geographers "have failed to devote sustained attention to speech as a practice that provokes meanings in, and of, different spaces" (2013, p. 207). In responding to Brickell's critique, our focus on narratives of place thus has two key purposes. First, it provides insights into immigrant identities, by illustrating the ways in which recent immigrants describe themselves through the act of talking about place. Second, it shows how individual narratives of place act as a form of place-making, creating situated understandings of home and belonging. Our account is informed by discourse analytical approaches to the interview that see it as a social practice and not merely as a research instrument (Krzyżanowski and Wodak 2008). Instead of taking what is said at face value, discourse analytical approaches (Johnstone 2008) argue that interviewees use language in order to "imbue life events with a temporal and logical order, to demystify them and establish coherence across past, present, and as yet unrealized events" (Ochs and Capps 2001, p. 2). This approach allows us to illuminate social actors' situated conceptualization of abstract 
notions such as place, identity, home and belonging and their relationships to each other, through an analysis of how representations of place and connections among places and between them and their constituents (people, actions, experiences) are constructed in personal narratives using semiotic resources such as language. This offers, we suggest, new insights into immigrant identity and place, illustrated here through the example of Ireland. The paper begins with a brief overview of the Irish context and a broader description of the research project and participants. It continues with a general discussion of the ways in which research participants narrate place and identity. In the next section, we discuss the explicit ways in which research participants linked place and identity in their narratives through the use of the concept of "home." We conclude with a brief reflection on how detailed attention to narrative provides new insights into the complex relationship between immigrant identity and place.

\section{The context for the research}

In the period from 2000 to 2012, almost 1 million people immigrated to the Republic of Ireland. The majority were EU nationals, ranging from $87.4 \%$ of all immigrants in 2007 to $76.5 \%$ in 2012 (Gilmartin 2013). Ireland had long been an immigrant destination for EU- $15^{3}$ nationals, for example people from the UK, Germany, France, and Italy. However, with the enlargement of the EU in 2004, Ireland's decision to grant immediate rights to work and live in the country to new EU nationals meant that it quickly became a destination for immigrants from Poland, Lithuania, and Latvia in particular. By 2007, $56.5 \%$ of all immigration to Ireland came from the EU- $10^{4}$ countries (Gilmartin 2013). EU nationals are free to move to and work in Ireland. In contrast, people from outside the EU require special permission-such as work permits or student visas - to move to Ireland for longer periods, and to work in Ireland.

In the period from 2002 to 2011, the population of Ireland born outside the country increased from $10.4 \%$ to $16.9 \%$ (Gilmartin 2013, p. 95). Our research took place against this backdrop of significant change in the population structure of the country. In late 2008 and during the greater part of 2009, we interviewed 60 people who had moved to Ireland either in 2004 or in 2007. Since the project had a longitudinal focus, we carried out repeat interviews during the latter part of 2010 and early 2011. Interviewees had thus spent between one and five years in Ireland by the time of their first interview and between three and eight years by the time of their second interview. We contacted potential interviewees using several methods such as snowballing, a parenting website for expat mothers and through leaving information in various public locations, such as libraries, throughout Ireland which allowed people to self-select. Interviewees decided where the interviews would take place. Some people wanted to be interviewed in their homes, and we met others in quiet cafes or bars. All the interviews took place in a relaxed 
environment and had a semi-guided format: we covered an agreed set of topics (e.g., reason for coming to Ireland, impressions of Ireland, attitudes about things Irish, experiences on the job market and at work, social life, services, long- and short-term plans) without imposing a particular order. Following introductory questions about arriving in Ireland we let interviewees develop their own narratives which we furthered by both clarification-type questions and comments. Some interviews involved both authors, others were conducted by only one of us. This influenced the interview: the fact that one author is Irish and the other German meant that interviewees often framed or qualified their remarks based on who they were addressing. As a result, interviews with both authors present often took a different shape and direction to those with just one author in attendance.

Participants are representative of Ireland's immigrant population. Most of them came from European countries, but there also were people from countries such as the USA, Australia, Canada, India, and South Africa. In total, the 36 women and 24 men came from 18 different countries, were aged between 22 and 68 at the time of the first interview and lived in a range of locations across Ireland (see Table 1). People's reasons for moving to Ireland were varied, and included work, study, language skills, adventure, and

Table 1. Overview of research participants by nationality group, gender, age, and place of residence.

\begin{tabular}{|c|c|c|c|c|c|c|c|c|c|}
\hline \multirow[b]{3}{*}{ Nationality } & \multicolumn{8}{|c|}{ Age and gender } & \multirow[b]{3}{*}{ Place of residence } \\
\hline & \multicolumn{2}{|c|}{$15-24$} & \multicolumn{2}{|c|}{$25-34$} & \multicolumn{2}{|c|}{$35-54$} & \multicolumn{2}{|c|}{$55+$} & \\
\hline & $\mathrm{F}$ & M & $\mathrm{F}$ & M & $\mathrm{F}$ & M & $\mathrm{F}$ & M & \\
\hline Ireland & 0 & 0 & 0 & 0 & 2 & 0 & 0 & 0 & Greater Dublin region (2) \\
\hline UK & 0 & 0 & 1 & 2 & 3 & 4 & 1 & 0 & $\begin{array}{l}\text { Greater Dublin region (5); } \\
\text { South (2); Southeast, } \\
\text { West, Southwest, } \\
\text { Northwest (1 each) }\end{array}$ \\
\hline Rest of EU-15 $5^{\mathrm{a}}$ & 1 & 0 & 8 & 2 & 2 & 4 & 0 & 0 & $\begin{array}{l}\text { Greater Dublin region } \\
\text { (12); South (4); } \\
\text { Northwest (1) }\end{array}$ \\
\hline $\mathrm{EU}-12^{\mathrm{b}}$ & 0 & 0 & 4 & 2 & 1 & 4 & 0 & 0 & $\begin{array}{l}\text { Greater Dublin region (9); } \\
\text { West, Northwest (1 each) }\end{array}$ \\
\hline US & 4 & 0 & 2 & 2 & 2 & 1 & 0 & 0 & $\begin{array}{l}\text { Greater Dublin region (8); } \\
\text { North (2); South (1) }\end{array}$ \\
\hline Rest of world ${ }^{\mathrm{c}}$ & 2 & 0 & 1 & 1 & 2 & 2 & 0 & 0 & $\begin{array}{l}\text { Greater Dublin region (5); } \\
\text { Southeast, Southwest, } \\
\text { Northwest ( } 1 \text { each) }\end{array}$ \\
\hline Total & 7 & 0 & 16 & 9 & 12 & 15 & 1 & 0 & \\
\hline
\end{tabular}

${ }^{\mathrm{a}}$ Finland (1), France (2), Germany (3), Italy (9), the Netherlands (1), Spain (1); ${ }^{\mathrm{b}}$ Poland (9), Slovakia (1), Slovenia (1); ${ }^{c}$ Australia (1), Canada (2), China (1), India (2), South Africa (1), Uganda (1). 
relationships (see Gilmartin and Migge 2013). Building on a previous project (MCRI 2008), we decided not to focus on specific groups defined by nationality because we found that nationality was only one of several factors that influenced people's lives in Ireland. So-called national communities are socially heterogeneous and on their own insufficient for understanding immigrant identities (Krzyżanowski and Wodak 2008, p. 98). Instead, national identification needs to be examined in conjunction with micro-social factors, as migration "remains a singular, subjective and unique experience which resists generalization" (Krzyżanowski and Wodak 2008, p. 98).

\section{Narrating place and identity}

Building on the approach advocated by De Cillia et al. (1999), we discuss both the content of descriptions and the linguistic strategies that are used by immigrants to describe the places they lived in and their experiences in Ireland, and the changes that occurred. By content, we refer to the topics people mentioned to when they directly answered our questions about specific places, whether these were the local areas where they lived or more abstract scales such as the nation, as well as the people who inhabit them. By linguistic strategies, we refer to the different ways in which people represent places through language. Both content and linguistic strategies provide insights into place and immigrant identities. De Cillia et al. were most interested in the linguistic strategies used to promote national identities, but we find their distinction between constructive, perpetuating, and dismantling linguistic strategies of broader relevance (1999, pp. 160-161). Constructive strategies aim to build identities, and seek to create a sense of shared identity or solidarity around a sense of "us" or "we." Perpetuating strategies seek to maintain identities, by supporting and defending continuity. Dismantling strategies, in contrast, serve to challenge or demythologize or demolish existing identities. When applied to immigrant narratives, these linguistic strategies serve to construct, maintain or challenge broadly accepted or "common-sense" understandings of place, whether local, urban, or national, as well as individual and collective identities. In this section, we discuss the general themes that emerged across our repeat interviews to show the commonalities in how immigrants narrated both place and identity.

When we asked people about living in Ireland, three broad topics dominated: the physical landscape, the built environment, and social interactions. People in both urban and rural areas regularly described the physical beauty of the natural landscape. Talking about how it felt to show friends around in her new house, one interviewee from the UK said: "when the weather is good you forget where you are when you are here. You are looking out and thinking I am near the sea, the fresh air and it is absolutely beautiful" (2007UK05). ${ }^{5}$ Descriptions of the beauty of the natural landscape often contrasted with negative reactions to weather and to the built landscape. ${ }^{6}$ The quote above is qualified with reference to the weather: the place is 
beautiful when "the weather is good." This was often contrasted with negative reactions to weather in Ireland. A Polish man in Dublin highlighted the wind and the rain as things that he dislikes, describing them as physically painful:

The only thing I don't like in Ireland is rain. The weather is, when it is winter it is still windy and the rain is smashing your face. (2004POL02b)

Others described the weather simply as depressing, and as a metaphor for a more general dissatisfaction with Ireland. People were also critical of the built environment, which at times contributed to a sense of alienation. This was particularly the case for immigrants from other European countries, who highlighted the backwardness of Ireland's built environment in comparison to larger continental European countries. Yet, despite these initial assessments, people often spoke about how their attitudes to the built landscape had changed, and how they had grown to accept and like the place where they lived.

The third topic that dominated was social interaction and friendships. Irish people and the overall atmosphere in Ireland were generally experienced as positive and welcoming, though there was a sense that this friendliness was quite shallow. Many people suggested "that it is very easy to hang on [out] with Irish people but then it's not easy to become real friends. To know really who they are, what they want. At some stage you can't be closer to them" (2004IT04) because people eschewed serious topics and personal issues. ${ }^{7}$ In contrast to a broader literature on cosmopolitan belonging (see, for example, Binnie et al. 2006; Vertovec 2007), we found that interviewees living in rural areas were more likely to invoke friendship and neighborhood networks in their description of place and identities. Comparing rural Ireland to the UK, a UK-Spanish couple told us that they felt at home very quickly in the rural southeast mainly because of the friendly and helpful attitude of their neighbors who provide a great support network for them:

Interviewee (M): Yes or even here, the neighbours here, they are very good. We said we have come here to be one of you, not to be different or anything. We are very lucky with them, we had this bad weather and they are coming to see if we are all right or they phoned to see if we needed anything. They are nice. It won't happen in England I think.

Interviewee (F): Certainly not the part we lived in anyway.

Interviewee (M): And for me that is very very important. (2004UK06)

The topics that people highlighted were thus material and tangible: weather, natural and built environment, and the quality of social engagement and interaction. We next discuss the ways in which people talked about these topics through a focus on linguistic strategies.

The linguistic strategies that people used were varied. When we started this project, we expected people to describe their identities in relation to place, whether that was local, national, or at some other scale. However, people 
rarely articulated a place-based identity without prompting from us. When we asked, though, several of the interviewees strongly aligned with their country of origin: these are clear examples of perpetuation strategies as immigrants seek to assert their national identity from a different spatial context. In the following array of quotes, we can see the modifiers of definiteness (absolute, definitely) and current relevance (still) in these quotes. They convey the sense that national identity is an immutable characteristic of their personality which has not been affected by having lived abroad for many years:

I am still very clearly English ... [it is] an absolute part of who I am, I don't want it to go. (2004UK05)

there are two things I don't lose at all, my accent and my passport. (2004UK06)

Interviewer: Do you still think of yourself as South African?

Interviewee: Yes definitely. (2007SA01)

Interviewer: So would you say that you are turning Irish or that you are adopting more Irish things?

Interviewee: Personally I don't, in my mind I am an Indian. (2007IN02)

Others are less definite, but also seek to perpetuate their sense of their own national identity. Here, a Polish interviewee argues that he will always maintain a primary Polish identity: he asserts this through the repeated use of the word still (a continuative modifier):

No I am still Polish. Just you know I spent here 5 years. [...] But it is still, my Polish background, my education, my name like the influence which I get by my parents, my school whatever. I am still thinking in that way. [... if I] had a kid here for them that would be like they could be the part of Irish society in full because if somebody is, was born in the country that terminates that. You belong to the place you was born. I was born in Poland so you know if I have a very good time here still it is like my brain works in the Polish way. (2004POL02) (italics added)

In addition to perpetuation strategies, immigrants often used comparison, particularly the identification of difference, to construct and dismantle perceptions of Ireland and their place of origin. We found that comparisons frequently served to simultaneously construct and dismantle: though we rarely asked directly about people's place of origin, interviewees nevertheless made comparative reference to it when discussing issues related to Ireland. Most interviewees spoke positively though generally not in what could be classed "idyllic" terms about their country of origin. Apart from invoking important social relationships, they also highlighted a range of positively valued stereotype-like properties about these countries. For example, people presented their country of origin in general and various of its institutions and practices in particular as (more) orderly and rule- or principle-governed in comparison to 
Ireland. As an example, an American woman who obtained residency in Ireland despite not being married to her Irish partner implied that in the US immigration follows strict procedures and rules: "Yes, there would be a few countries which would allow someone's partner to live there but not very many, we could never go and do this in the United States unless we were married" (2007US04).

Critical assessments of the country of origin were also present, particularly directed at co-nationals. Strikingly, people from Poland probably voiced the greatest amount and strongest types of criticism about their co-nationals, both those living in Poland and those in Ireland. Two interviewees with some qualification characterized Polish people as discriminatory and close-minded: "Poland would be a bit racist country like, it is not like for the blacks" (2004POL01). Many Polish interviewees recounted how they are often either cast as failures or traitors because they decided to leave Poland or are thought of simply as financial resources for the people back home. In fact, many people implied that (temporarily) leaving Poland was prompted by a desire to escape the narrow confines of Polish life and to broaden their minds. While people sometimes also extended such negative descriptions to members of their own family, it seems to us that these starkly negative descriptions are linked to issues of class. For instance, one Polish woman argued that the negative stereotypes apply to people who work in the construction industry, i.e. less well-educated people. She said: "I just can't understand people who have been living in a country for a number of years and can't say a word of English, they must be really stubborn. How could you not pick up or know some words?" (2004POL01). She, and others who used such descriptions, were mostly of middle-class backgrounds. They used distancing language, for example "they," to clearly distinguish themselves from working-class Poles who, in their view, were responsible for negative opinions about Poles. This shows the complex relationship that immigrants have with both place and identity, where a narrative of separation is used to disrupt any sense of a shared identity with immigrants on the basis of a common country of origin, and dismantling strategies are used in relation to the place of origin.

\section{Place-based identities: narratives of home}

In this section, we provide a more detailed discussion of the relationship between immigrant identity and place through a specific focus on the concept of "home." There is a growing body of work on home within geography (see Blunt and Dowling 2006; Skey 2011). In their recent review of this literature as it relates to migration, Ralph and Staeheli (2011) suggested that "home" should be understood in conjunction with "belonging." These two concepts yoke identity and place together, with home "located in the complex relationships through which migrants and others build and interpret lives" (Ralph and Staeheli 2011, p. 522). See also Wright 2014). In this section, we look at how notions of home are represented and negotiated in the narratives of a small number of research participants (see Table 2) and the insights this 
Table 2. Demographic characteristics of selected research participants.

\begin{tabular}{lllllll}
\hline Identifier & Gender & Age & Education & Family status & Position & Place of residence \\
\hline 2004UK01 & Male & $35-54$ & Third level & Single & Lecturer & Greater Dublin region \\
2007UK01 & Male & $25-34$ & Third level & Relationship & Architect & Greater Dublin region \\
2004POL02 & Male & $25-34$ & Third level & Relationship & Artist & Greater Dublin region \\
2004UK05 & Female & $25-34$ & Second level & Relationship & Administrator & Greater Dublin region \\
2007SLO01 & Female & $35-54$ & Third level & Single & Lecturer & Greater Dublin region \\
2007SPN01 & Male & $25-34$ & Third level & Relationship & Childcare & Greater Dublin region \\
2004POL03 & Male & $25-34$ & Second level & Single & Bar worker & Northwest \\
\hline
\end{tabular}


provides into people's sense and ways of conceptualizing place and identity. ${ }^{8}$ Narrators build representations of place and place-belongingness through the creation of stories. In these stories, people forge connections between places, people, actions, and emotions that allow insights into their understanding of concepts of home "because it allows the investigation of traits that are seen as salient" (De Fina 2006, p. 351). Through detailed textual analysis, we stress the local occasioning of such categories: people's constructions are not fixed but are situated and shaped by the interaction (and also shape the interaction itself). In our analysis of interview narratives, we were interested in whether home had one or multiple referents; what kinds of places were defined as home; what makes people feel at home; and how these narratives change over time. This allows us to understand the variation in people's construction of the notion of "home" and its relationship to identity.

Our sample included people for whom home had a singular referent. For instance, an interviewee who grew up in the UK but now lives in Dublin (2004UK01) used perpetuating strategies to identify home with a certain region in England. On prompting, he explains that he considers it home because it is a place he is familiar with-"where I grew up"-and he has family links "that's where my parents live." The use of just ("It's just where I grew up and that's where my parents live.") and the unmitigated summary statement of "that's where I'm from" seek to actively limit the interpretation of home to these two factors, possibly as an attempt to ward off negative reactions from the Irish interviewer. This is reasserted a little further along, when he restates "Yes and the fact that that's where I am from," in response to the interviewer's probing question of whether family is really all that attaches him to England. Dublin, in contrast, is not identified with any personal relationships, but he sees strong parallels in terms of the built environment between the two places ("You know lots of semi-detached and stuff. Just general suburban [...].") They induced feelings of familiarity, but did not lead to feelings of positive attachment to Dublin. In fact, by negatively connotating these similarities as "uncanny" and suggesting that they are the result of negative processes such as "conspicuous consumption," he appears to be downplaying their significance and denying the possibility that this similarity could constitute an emotional attachment to Dublin. A Polish interviewee also claims only a singular identity, Polish. However, in contrast to the interviewee from the UK, he foregrounds issues of socialization as central in defining home because according to him such processes are not reversible and thus tie you to that place no matter how you feel about a new place ("I was born in Poland so you know if I have a very good time here still it is like my brain works in the Polish way" [2004POL02]).

It was more common, however, for people to have less bounded and more ambivalent understandings of "home." As discussed by Krzyżanowski and Wodak (2008), interviewees who were ambivalent about their belonging often relied on metaphoric expressions in order to express their understanding of home. An interviewee who came from Wales to Ireland, but whose parents 
were originally from the west of Ireland and who had strong family connections to Ireland, expresses his ambivalence about his sense of national and cultural belonging by likening it to a dilemma about which side to support in a sporting event involving two familiar teams:

\begin{abstract}
Extract (1)
Interviewer 1: So if we were to ask you where is home? What would you say?

Interviewee: The only way to kind of phrase it like you know when Wales used to be kind of playing in Ireland in rugby like you know. Where you kind of, but I always kind of saw myself like in a bit more kind of, like the whole kind of Wales [unclear] because Dad and Mum just moved there for work you know. Dad got a job there like and then, but then like all my kind of relatives are Irish then like you know so I kind of struggle with the whole kind of Welsh thing anyway like you know like because most of my friends would be Welsh through and through like so. (2007UK01)
\end{abstract}

However, ultimately he makes it clear that he considers himself Irish, rather than Welsh. Discursively, he first constructs the greater salience of his Irishness/Ireland by identifying them with primary or significant social relationships, namely parents, and the immediate wider family ("but then like all my kind of relatives are Irish"). Thus, it is ancestry and family relationships that create belonging. Wales, by contrast, cannot serve for identification because it is only linked to friends, a more ephemeral category of people. Second, his own (and his family's) presence in Wales is depicted as resulting from an externally induced necessity "Dad got a job there like." Third, Welshness is cast as an unclear or unpenetrable category for him ("I kind of struggle with the whole kind of Welsh thing anyway like") that is also unattainable for him because it requires Welsh roots ("being Welsh through and through"). He underscores his emotional distance to Wales further by using the distal deictic element "there" to refer to it ("moved there") suggesting that he considers it to be at a remove from him. However, this broad black and white categorization does not seem to sufficiently capture his sense of home because immediately after this turn, he independently returns to the issue, narrowing the notion of home to a specific location, his home town in Wales.

\title{
Extract (2)
}

Interviewee: [...] But I don't know home would always be [town] I suppose that's where I grew up like and that's where my kind of friends are and stuff so and it's great to go back and it's a great kind of town to go back over Easter and Christmas and it's night to kind of thing [sic] but yes it's kind of, I don't mind coming away from it either like so.

In Extract (2) he explains that he considers his hometown "home" because it is linked to the fact that it is loaded with growing up and friends. However, 
neither appear to be part of his primary sense of self because he does not "mind coming away from it either." Part of the reason seems to be that his friendship networks are no longer locally based because "a lot of people have kind of moved to Cardiff and yes it would be that kind of town like you know so they would be just back at Christmas and Easter and that kind of thing like so." His narrative thus contains a complex and at times contradictory mix of constructive, perpetuating and dismantling strategies that are rarely resolved over the course of two interviews.

Other interviewees also assert association to two places, but do not present this as a dilemma or something that is in need of justification. A Spanish interviewee for instance uses constructive strategies to assert that he now has two homes since he moved to Ireland ("I have two homes now").

\section{Extract (3)}

Interviewer 1: So if I ask you where you think home is? Where is your home?

Interviewee: I have two homes now.

Interviewer 1: Really.

Interviewee: Yes, really.

Interviewer 1: So Barcelona?

Interviewee: Really is that a really clear answer? Yes I cannot say that this [Dublin] is my home or just one is my home both [Dublin and Barcelona] are, both are because I am feel really good here [Dublin] as well. While you are on holidays you still remember in here, your flatmates, your things to do. I don't know so. (2007SPN01)

As he explains in Extract (3), home crucially includes positive feelings of being "at home" in a place and remembering things linked to it when you are away. Thus home may have several referents for him. In his narrative, Barcelona is linked to family, a great outdoor lifestyle and a love for the city and its language while Dublin-described somewhat negatively as "a small city" that is claustrophobic at times and with a dull lifestyle ("for me it's quite tough being work, home, pub, home, work") — is nevertheless linked to positive emotions and meaningful social relationships such as good flatmates, an Irish girlfriend and being independent from his parents.

A somewhat different approach was adopted by another interviewee from the UK (Extract 4). Unlike other interviewees who seem to conflate notions of identity and home, she delinks them. On the one hand, she uses perpetuating strategies to stress the continued relevance ("still") and unchanged nature ("clearly") of her English identity and its non-negotiability ("absolute part") and importance through the use of adverbial modifiers and a slightly qualified ("probably") statement asserting her lack of alignment with Irishness. On the other hand, however, she declares Ireland/Dublin as home using constructive linguistic strategies: 
Extract (4)

Interviewee: but I am still very clearly English. And I would get offended probably if somebody said to me I was getting an Irish accent, and that is honest. But that is because being English is an absolute part of who I am, I don't want it to go.

Interviewer: Where do you think of as home?

Interviewee: Here [Dublin].

Interviewer: So it is where you are living and feel safe and so on.

Interviewee: Yes it is. And I know it is very easy to go straight back to England but I think I would feel a lot more anonymous in England, being such a larger place [unclear] what you are able to give back to society. Here you [unclear] a smile on your face or ... do you know what I mean?

Interviewer: I do actually. Here it is all about easy conversation and

Interviewee: Yeah and I feel that there are a lot more people here who are prepared to do things for you just because they are a friend of a friend and I like that sometimes. In business maybe it is not so good but in friendship it is great. Somebody will say [unclear] I'll get him to get you something cheap in this place, or sort you out, or give you a lift home, I have two friends driving that way that night. You wouldn't get that so much in England. (2004UK05)

In this case, home is also not associated with significant personal social relationships and/or ancestry but with the fact that Dublin and its inhabitants generate feelings of connectedness for her.

An interviewee from Slovenia also dissociates home from feelings of identity, but in a somewhat different manner, highlighting the restrictive nature of European national identities. She considers Slovenia and Ljubljana as home because that is where she is from and where her family lives. However, she is unsure whether she can still claim Slovenian identity because having lived outside of Slovenia she has changed — she has become culturally hybrid: "I am not sure if I fit there completely anymore because I lived in Sweden I picked up Swedish things. I am living here [in Ireland] now I am picking Irish things" (2007SLO01). To resolve the dilemma posed by hybridity, she uses constructive strategies to align with a higher-level identity, European, that by its very nature is fuzzy and not fixed, but promotes hybridity: "I think of myself as European because I don't think I fit anywhere like somebody who has never moved anywhere." Her depiction of the perfect place to live (Extract 5) further confirms her synergistic orientation to issues of identity and ultimately also home:

\section{Extract (5)}

I was joking the other day. The best solution for me or the best ideal place I would like is to take Stockholm because it's a beautiful city on the sea and everything and the lakes and so on. Put it in the Alps so I can go skiing in half an hour [laugh]. Put [workplace] in Stockholm and my colleagues there and then 
bring my Slovenian friends there and that would be like, and put it somewhere where the climate is nice [laugh]. That would be ideal but obviously it's not going to happen. (2007SLO01)

A similar synergistic approach to identity and home is also taken by other interviewees from Europe who have lived in or have close connections to a third or fourth European country. Rather than aligning with one or the other for identity purposes, they claim a supranational cultural identity. Such supraidentities are not only useful for avoiding overt alignment with possibly stigmatized national identities but are also used to project a modern sophisticated cultural identity that is not based in nationalist traditions.

We also found that conceptualizations of home and people's identities were dynamic, influenced by a variety of events and circumstances. For instance, in the second interview, after having spent three years in Ireland, the interviewee from Wales with Irish family roots asserted an even stronger alignment with Ireland despite having suffered the negative effects of the recession firsthand. He suggests, though still tentatively ("well I suppose"), that Ireland has changed from being a place of cultural belonging determined by his family ties to one that has become associated with positive feelings ("happy") and new important social connections ("my girlfriend is here too").

\section{Extract (6)}

Interviewer: $[\ldots]$ so what really makes you hold on to Ireland? [...]

Interviewee: Well I suppose when I came over I was [unclear] kind of happy and then my girlfriend is here as well, she is in Dublin as well. (2007UK01b)

He now considers it his home because even if he had to move away from Ireland, he argues, that would only be a temporary move. He also offers rational reasons for "holding out" in Ireland, namely the fact "that when you are talking about going over to the UK, it seems like all the roads lead to London and I wouldn't be that keen to head to London," and "but also because the bosses here, I have been told they were thinking that it would pick up and something would come in." Note that he uses the directional expression "going over" instead of "returning to," a dismantling strategy which suggests that this point of reference is now Ireland rather than the UK, the place where he originates from.

The Spanish interviewee's sense of home had also changed between the two interviews which were about a year apart, in the middle of Ireland's economic downturn. However, in this case, the interviewee's sense of attachment to his city of origin, Barcelona, rather than Dublin, his current place of residence, appears to have deepened and is expressed by a greater use of perpetuating and dismantling linguistic strategies. Barcelona continued to be depicted in a positive light and as a place to spend one's life. By contrast, 
Dublin had become a place full of negative experiences and negative energy that compared negatively to Barcelona. The only positive emotional attachment to Dublin that he was still confident about was his girlfriend (Extract 7):

\section{Extract (7)}

Interviewer: So do you think then that one of your main reasons to still be here is your girlfriend?

Interviewee: Yes. (2007SPN01b)

Besides this emotional link, he now only invoked purpose-based aspects such as the fact that he was determined to pass his advanced English certificate, that his girlfriend had not yet finished university and that he was still gaining work experience that continued to link him to Dublin. Both the work experience and the English language certificate were presented as being "important for me, for my life, my career and for my pride," but these were always firmly located back in Barcelona. Essentially, Ireland had become a place for gathering experiences for a better life in the near future in Barcelona. There were also people whose sense of attachment to Ireland and overall identity had ultimately not changed. The man from the UK who had a singular referent for home (2004UK01), for instance, reasserted this perspective during his second interview (Extract 8), showing the same kind of noncommittal alignment to Ireland:

\section{Extract (8)}

Interviewer: [...] How do you feel about living in Ireland now?

Interviewee: It is fine, I was happy enough before.

Interviewer: And you are still happy enough?

Interviewee: Yes.

Interviewer: And is there any change in the quality of the happiness from the last time to this time?

Interviewee: It is about the same.

Interviewer: And in terms of your future plans, do you see yourself remaining here?

Interviewee: Probably not forever, no. But for the next couple of years

Interviewer: For the next few years staying here?

Interviewee: I think so, yes. (2004UK01b)

In general, though, we noted ambiguity and complexity in how people talked about home, both in terms of the content of their discussions and in the ways that this was expressed. Often, we found that immigrants would talk about home in contradictory and conflicted ways, particularly when they tried to 
reconcile the need for independence with the pull of emotional attachments or responsibilities. For example, a young Polish man (Extract 9) said:

\section{Extract (9)}

I don't miss Poland at all, I just miss my parents, that is it, that is the biggest reason to go there. And the other thing is I wouldn't leave my parents when they are older, I have to look after them. (2004POL03b)

Here, we see home articulated in terms of the pull of obligation and duty, a story that surfaced but was often suppressed in the interviews. Linguistically, we saw that people made use of indirect strategies such as the use of adverbial modifiers ("still," "kinds of," "definitely," "probably," "there," "completely") and directional verbs to put on record their orientation to and alignment with places and identities. In other cases, interviewees explicitly named the places they aligned and disaligned with as well as used bold statements ("yes," "here," "I have two homes now," "Yes and the fact that that's where I am from") to confidently assert their sense of self in response to our probing questions about home and belonging. In this way, a focus on narratives of "home" shows how immigrants, in an effort to foreground constructive strategies in relation to both place and identity, most often resort to an uneasy tension of perpetuating and dismantling strategies as they struggle to make sense of new or challenging place-based identities. Rather than asserting that attitudes to place and home are determined by fixed and predefined identities, our analysis shows how both place and identity are mutually constituted and persistently mutable for contemporary immigrants, with narrative as central to this process.

\section{Conclusion}

In this paper, we have suggested that a greater attention to narrative-in particular, through a microlevel discursive analysis of the linguistic strategies used by immigrants-offers new insights into the relationship between immigrant identity and place. We suggest that immigrants narrate place by focusing on three key topics. They talk about the physical landscape, the built environment, and social interactions. Drawing from De Cillia et al. (1999), we showed how immigrants use three linguistic strategies to discuss place and identity. These are constructive, perpetuating, and dismantling strategies, and we showed how each of these strategies often works through comparison. In fact, adding to the work of De Cillia et al., we show how comparison is a particularly important linguistic strategy for immigrants, because it allows them to make sense, construct, perpetuate, and dismantle their own and others' understanding of place and their relationship to place. Our analysis shows that comparison is central to immigrant discourses of place and identity: it is repeatedly used by migrants regardless of national, ethnic, or gender background (see Clary-Lemon 2010, for a discussion of comparison in 
the narratives of Irish migrants in Canada). Understanding the linguistic strategies of immigrants is important for two key reasons. The first is because they point to the ambivalence and fuzziness, as well as mutability, of individual perceptions. The second is because they point to processes of inclusion and exclusion that matter for immigrant integration and assimilation. Attention to language makes this ambivalence clearer, as we see how immigrant narratives construct place: as imbued with rich social relationships that are local and translocal, and as sites of ambiguous and changing meaning. These issues are developed in more detail in our discussion of "home," where we use a detailed analysis to show the linguistic strategies and means that immigrants use in relation to this concept. In particular, we showed how "home"- a concept that yokes together immigrant identities and place-is highly variable and conceptualized in different and at times contradictory ways for people.

It has been difficult for researchers to fully capture or show the complexity of the relationship between "place" and "identity," particularly in relation to immigrants. Our argument is that greater attention to language, taking inspiration from discourse analytical approaches, allows us to better show this complexity, because it takes language as a social practice rather than as a source to be mined for data. Paying attention to language then offers new insights into the relationship between immigrant identity and place, particularly the ways in which language is used —often simultaneously—to construct and dismantle place and place-based identities. Comparison is central to this process, yet comparison is also poorly understood within geography (Ward 2010; McFarlane and Robinson 2012). Our analysis points to both the importance of comparison in immigrant identity- and place-making, and to the centrality of language as a social practice to this process.

\section{Notes}

1. Tomaz is a pseudonym.

2. The project, entitled "Towards a dynamic approach to research on migration and integration," was supported by the Irish Research Council for the Humanities and Social Sciences.

3. EU-15 countries are Austria, Belgium, Denmark, Finland, France, Germany, Greece, Ireland, Italy, Luxembourg, the Netherlands, Portugal, Spain, Sweden, and the UK.

4. EU-10 countries are Cyprus, Czech Republic, Estonia, Hungary, Latvia, Lithuania, Malta, Poland, Slovakia, and Slovenia.

5. Interviewees are identified by the year of arrival in Ireland (either 2004 or 2007) and by a nationality identifier (for example, POL for Poland) and a numeric identifier. The use of "b" signifies the second interview with the interviewee.

6. The contrast between unspoilt depopulated natural landscapes and built landscapes is a common trope in writing on Ireland (Graham 1997; Duffy 2013).

7. It is worth noting that immigrants often comment on difficulties in making friendships with the settled population, across a range of spatial contexts. For 
example, Ryan et al. (2008, p. 682) discuss this phenomenon in the British context, while Gmelch (1980, p. 139) highlights "the friendliness of people at home" as a motivation for return migration.

8. In this section, we focus on the narratives of people who do not have children. We discuss the geographies of belonging of migrant mothers in Ireland in Gilmartin and Migge (forthcoming).

\section{References}

Antonsich, M., 2010. Searching for belonging - an analytical framework. Geography Compass, 4 (6), 644-659.

Binnie, J., et al., eds., 2006. Cosmopolitan urbanisms. Abingdon: Routledge.

Blunt, A. and Dowling, R., 2006. Home. London: Routledge.

Brickell, K., 2013. Towards geographies of speech: proverbial utterances of home in contemporary Vietnam. Transactions of the Institute of British Geographers, 38, 207-222.

Brickell, K. and Datta, A., eds., 2011. Translocal geographies: spaces, places, connections. Farnham: Ashgate.

Clary-Lemon, J., 2010. 'We're not ethnic, we're Irish!' Oral histories and the discursive construction of Irish identity. Discourse \& Society, 21 (1), 5-25.

Conradson, D. and Mckay, D., 2007. Translocal subjectivities: mobility, connection, emotion. Mobilities, 2 (2), 167-174.

De Cillia, R., Reisigl, M., and Wodak, R., 1999. The discursive construction of national identities. Discourse \& Society, 10 (2), 149-173.

De Fina, A., 2006. Group identity, narrative and self-representation. In: A. de Fina, D. Schiffrin, and M. Bamberg, eds. Discourse and identity. Cambridge: Cambridge University Press, 351-375.

Duffy, P., 2013. 'Through American eyes': 100 years of Ireland in National Geographic magazine. In: C. Crowley and D. Linehan, eds. Spacing Ireland: place, society and culture in a post-boom era. Manchester: Manchester University Press, 183-196.

Ehrkamp, P., 2005. Placing identities: transnational practices and local attachments of Turkish immigrants in Germany. Journal of Ethnic and Migration Studies, 31 (2), 345-364.

Gilmartin, M., 2013. Changing Ireland 2000-2012: immigration, emigration and inequality. Irish Geography, 46 (1-2), 91-111.

Gilmartin, M. and Migge, B., 2013. European migrants in Ireland: pathways to integration. European Urban and Regional Studies, doi:10.1177/0969776412474583

Gilmartin, M. and Migge, B., forthcoming. Migrant mothers and the geographies of belonging. Gender, Place and Culture.

Gmelch, G., 1980. Return migration. Annual Review of Anthropology, 9 (1), 135-159.

Graham, B., 1997. Ireland and Irishness: place, culture and identity. In: B. Graham, ed. In search of Ireland: a cultural geography. London and New York, NY: Routledge, 1-15.

Johnstone, B., 2008. Discourse analysis. 2nd ed. Malden, MA: Blackwell.

Kong, L., 2010. Global shifts, theoretical shifts: changing geographies of religion. Progress in Human Geography, 34 (6), 755-776.

Krzyżanowski, M. and Wodak, R., 2008. Multiple identities, migration and belonging: 'voices of migrants'. In: C.R. Caldas-Coulthard and R. Iedema, eds. Identity trouble: 
critical discourse and contested identities. Basingstoke: Palgrave Macmillan, 95-119.

Levitt, P. and Jaworsky, B.N., 2007. Transnational migration studies: past development and future trends. Annual Review of Sociology, 33, 129-156.

McFarlane, C. and Robinson, J., 2012. Introduction-experiments in comparative urbanism. Urban Geography, 33 (6), 765-773.

MCRI, 2008. Getting on: from migration to integration-Chinese, Indian, Lithuanian and Nigerian migrants' experiences in Ireland. Dublin: Immigrant Council of Ireland.

Mee, K. and Wright, S., 2009. Guest editorial. Environment and Planning A, 41 (4), 772-779.

Ochs, E. and Capps, L., 2001. Living narrative: creating lives in everyday storytelling. Cambridge, MA: Harvard University Press.

Peach, C., 2002. Social geography: new religions and ethnoburbs-contrasts with cultural geography. Progress in Human Geography, 26 (2), 252-260.

Pessar, P.R. and Mahler, S.J., 2003. Transnational migration: bringing gender in. International Migration Review, 37 (3), 812-846.

Ralph, D. and Staeheli, L.A., 2011. Home and migration: mobilities, belongings and identities. Geography Compass, 5 (7), 517-530.

Ryan, L., et al., 2008. Social networks, social support and social capital: the experiences of recent Polish migrants in London. Sociology, 42 (4), 672-690.

Sarbin, T.R., 1983. Place identity as a component of self: an addendum. Journal of Environmental Psychology, 3 (4), 337-342.

Silverstein, P.A., 2005. Immigrant racialization and the new savage slot: race, migration, and immigration in the New Europe. Annual Review of Anthropology, 34 (1), 363-384.

Skey, M., 2011. 'Thank god, I'm back!' (Re)defining the nation as a homely place in relation to journeys abroad. Journal of Cultural Geography, 28 (2), 233-252.

Tuan, Y.-F., 1991. Language and the making of place: a narrative-descriptive approach. Annals of the Association of American Geographers, 81 (4), 684-696.

van Riemsdijk, M., 2014. International migration and local emplacement: everyday place-making practices of skilled migrants in Oslo, Norway. Environment and Planning A, 46, 963-979.

Vertovec, S., 2007. Super-diversity and its implications. Ethnic and Racial Studies, $30(6), 1024-1054$.

Ward, K., 2010. Towards a relational comparative approach to the study of cities. Progress in Human Geography, 34 (4), 471-487.

Wright, S., 2014. More-than-human, emergent belongings: a weak theory approach. Progress in Human Geography, doi:10.1177/0309132514537132 